\title{
Mycoplasma phocidae sp. nov., Isolated from Harbor Seals (Phoca vitulina L.)
}

\author{
H. LOUISE RUHNKE ${ }^{1 *}$ AND SARABELLE MADOFF ${ }^{2}$ \\ Veterinary Laboratory Services, Ontario Ministry of Agriculture and Food, Box 3612, Guelph, Ontario, \\ Canada N1H $6 R_{8},{ }^{1}$ and Department of Bacteriology and Infectious Disease Unit, \\ Massachusetts General Hospital, Boston, Massachusetts $02114^{2}$
}

\begin{abstract}
In 1979 and 1980, more than 400 harbor seals (Phoca vitulina) along the New England coast of the United States died of epizootic pneumonia that was attributed to an influenza virus. Six mycoplasma isolates that were recovered from the respiratory tracts of affected seals were investigated and were found to be serologically identical and distinct from previously described species. These isolates required serum for growth, did not possess a cell wall, and did not hydrolyze urea. Arginine was hydrolyzed, glucose was not fermented, film and spots were observed on horse serum agar, phosphatase was produced, tetrazolium was not reduced, and serum and casein were not digested. The guanine-plus-cytosine content of the DNA was $27.8 \mathrm{~mol} \%$. We propose the name Mycoplasma phocidae for these isolates. The type strain of $M$. phocidae is strain 105 (= ATCC 33657).
\end{abstract}

In 1979 and 1980, an epizootic of pneumonia killed at least 445 harbor seals along the New England seaboard of the northeastern United States $(2,8,10,14)$. An influenza virus designated $\mathrm{A} / \mathrm{Seal} / \mathrm{Mass} / 1 / 80$ was isolated from the lungs of these seals. Specimens from affected seals were submitted to laboratories in both Guelph, Ontario, Canada, and Boston, Mass., and similar Mycoplasma strains were isolated from the lungs, tracheae, bronchi, and heart muscles. These isolates did not react with 55 antisera against previously described Mycoplasma species in immunofluorescence tests and were therefore believed to represent a new species (14). In this paper we describe the characteristics of the isolates and propose that they should be classified as a new species in the genus Mycoplasma, Mycoplasma phocidae; the type strain of this species is strain 105 (= ATCC 33657).

\section{MATERIALS AND METHODS}

Seals. Between December 1979 and March 1980 more than 400 harbor seals, most of them immature, died along the New England coast of acute pneumonia associated with influenza virus A/Seal/Mass/1/80/(H7N7). Lung tissue samples from eight animals that died were submitted for mycoplasma culture in Guelph, and lung, trachea, bronchus, and heart muscle samples from other animals that were sacrificed were examined in Boston.

Mycoplasma strains. Strains 84 and $105^{\mathrm{T}}(\mathrm{T}=$ type strain) were isolated in Boston from lung and trachea samples from seals that died, and strains M4359, M4360, M4361, and M4362 were isolated in Guelph from the pneumonic lungs of necropsied seals. The reference strains listed in Table 1 were obtained from J. G. Tully, National Institute of Allergy and Infectious Diseases, Frederick, Md., E. A. Freundt, WHO/ FAO International Reference Centre for Animal Mycoplasmas, Aarhus, Denmark, and R. H. Leach, National Collection of Type Cultures, Colindale, United Kingdom. Cultures of and antisera to Mycoplasma phocacerebrale $1049^{\mathrm{T}}$ and Mycoplasma phocarhinis $852^{\mathrm{T}}$, two new species that were isolated from seals, were kindly supplied by H. Kirchhoff, Hannover, Germany.

Media, cultivation, and purification. Specimens were cul-

\footnotetext{
* Corresponding author.
}

tured by using mycoplasma broth and agar $(12,16)$ containing horse serum or swine serum (at Guelph) and GIBCO horse blood brucella agar (at Boston). Cultures were incubated at $37^{\circ} \mathrm{C}$ in air containing $7 \% \mathrm{CO}_{2}$ and also anaerobically (Gaspak $\mathrm{CO}_{2}+\mathrm{H}_{2}$ ). For ureaplasma cultures we used mycoplasma broth adjusted to $\mathrm{pH} 6.0$ and Shepard A3 agar containing $0.015 \%$ manganese sulfate (17). Ureaplasma agar plates were incubated anaerobically as described above. The isolates were plate cloned four times and then passed through a membrane filter (average pore diameter, $450 \mathrm{~nm}$ ).

Characterization studies. Morphology was examined by using light microscopy, dark-field microscopy, and electron microscopy. Ultrathin sections of organisms that were grown for $48 \mathrm{~h}$ in an agar overlay were prepared for electron microscopy by previously described methods (4). Tests for absence of reversion were performed by subculturing the preparations seven times in broth that did not contain bacterial inhibitors and subculturing at each passage onto blood agar plates after $24 \mathrm{~h}$ of incubation. Filterability was tested by using membrane filters with pore diameters of 450 and $220 \mathrm{~nm}$. The sterol requirement was tested by determining susceptibility to $1.5 \%$ digitonin and growing the organisms in medium that did not contain serum (7). The guanineplus-cytosine $(\mathrm{G}+\mathrm{C})$ contents of strain $105^{\mathrm{T}}$ and $\mathrm{M} 4359$ DNAs were determined for us by J. Flossdorf, Gesellschaft fur Biotechnologische Forschung, Braunschweig, Germany (6). Other biochemical and biological properties were tested by using the methods described by Aluotto et al. (1).

Serological tests. Antisera to strains $105^{\mathrm{T}}$ (Boston) and M4359 (Guelph) were prepared in rabbits and were used in the direct and indirect immunofluorescence tests $(5,15)$ and in the growth inhibition test (3) against the reference strains listed in Table 1. Antisera for reference strains were prepared in Guelph or were obtained from the National Institute of Allergy and Infectious Diseases, Frederick, Md., the WHO/FAO International Reference Centre for Animal Mycoplasmas, Aarhus, Denmark, or R. Del Giudice.

\section{RESULTS AND DISCUSSION}

Strains $84,105^{\mathrm{T}}$, M4359, M4360, M4361, and M4362 grew well on mycoplasma media containing either horse or swine serum or on horse blood agar and produced typical fried egg colonies. Film and spots were observed on horse serum 
TABLE 1. Mycoplasma and Acholeplasma strains and antisera used in comparative serological tests with the seal mycoplasma

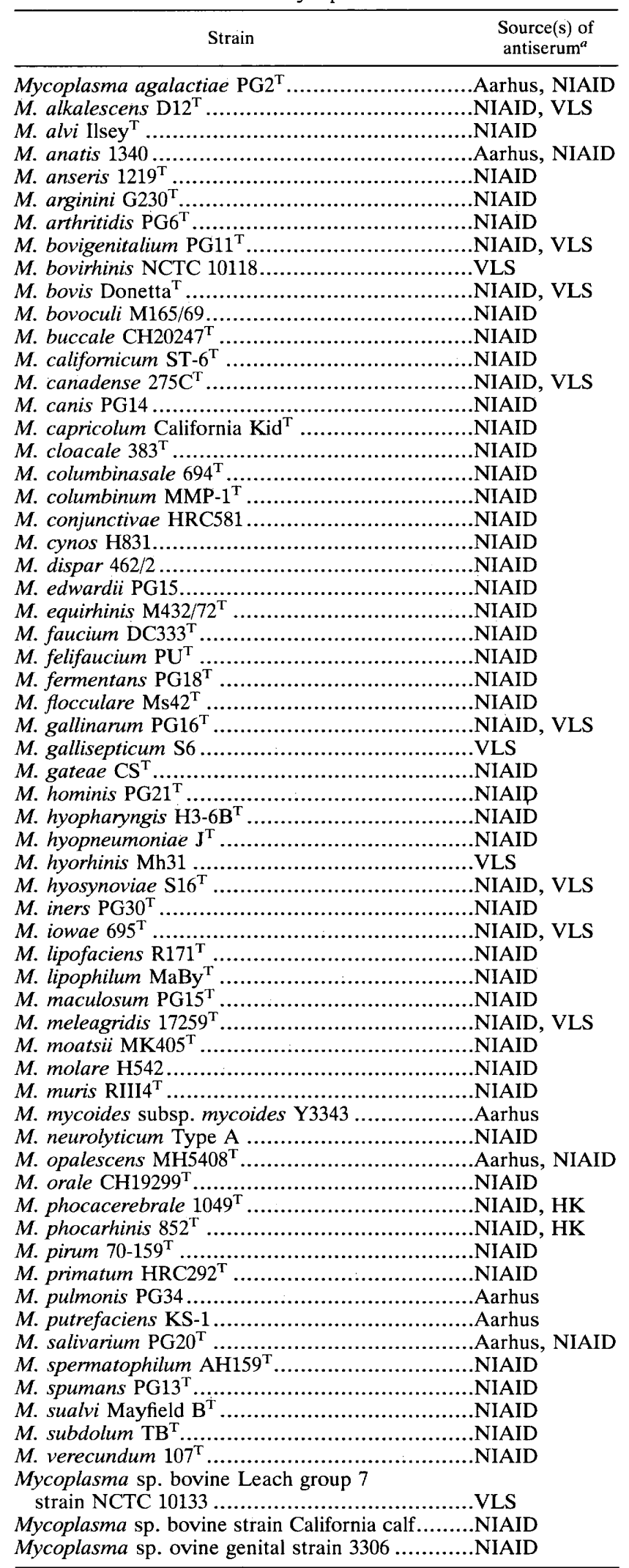

TABLE 1 -Continued

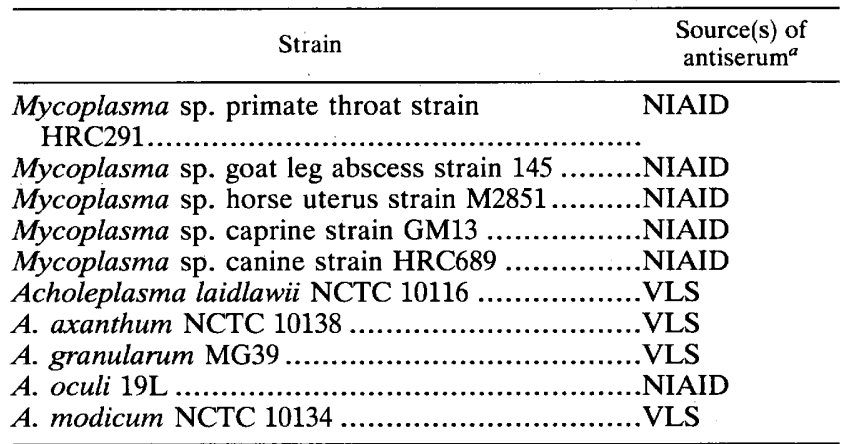

${ }^{a}$ Abbreviations: Aarhus, E. A. Freundt, WHO/FAO International Reference Centre for Animal Mycoplasmas, Aarhus, Denmark; NIAID, J. G. Tully, National Institute of Allergy and Infectious Diseases, Frederick, Md.; NCTC, R. H. Leach, National Collection of Type Cultures, Colindale, England; HK, H. Kirchhoff, Hannover, Germany; VLS, Veterinary Laboratory Services, Guelph, Canada.

agar. Growth appeared to be better on medium containing swine serum, and growth was enhanced by carbon dioxide enrichment or in an anaerobic environment. Ureaplasma sp. was not isolated. Morphological examination by phasecontrast microscopy revealed mostly coccoid forms with some pleomorphism and filaments that were 0.1 to $0.4 \mu \mathrm{m}$ in diameter, but no helical forms were observed. Electron microscopy of ultrathin sections of colonies on agar revealed pleomorphic, round, and coccoid forms that possessed a three-layer membrane and no evidence of a cell wall (Fig. 1).

There was no evidence of reversion to bacterial forms after seven passages in medium that did not contain bacterial inhibitors. The organisms passed freely through filters with pore diameters of $450 \mathrm{~nm}$ but were retained by filters with 220 -nm pore diameters. All of the strains were susceptible to $1.5 \%$ digitonin (zone of inhibition, $8 \mathrm{~mm}$ ), and there was no growth on medium that lacked serum. The average $\mathrm{G}+\mathrm{C}$ content of the DNA was $27.8 \mathrm{~mol} \%$ for strains $105^{\mathrm{T}}$ and M4359.

The results of other biochemical and biological tests are given in the species description below.

Strains $105^{\mathrm{T}}$, M4359, M4360, M4361, and M4362 were identical to each other, and there were no cross-reactions with $M$. phocacerebrale or $M$. phocarhinis. There was no serological evidence of a relationship with any other nonfermenting or arginine-hydrolyzing members of the genus $M y$ coplasma. Thus, we concluded that these strains represent a new species of the genus Mycoplasma in the class Mollicutes as defined by the International Committee on Systematic Bacteriology Subcommittee on the Taxonomy of Mollicutes (13). We propose that this organism should be assigned to the family Mycoplasmataceae and the genus Mycoplasma on the basis of its requirement for sterol and its lack of urea utilization, and we suggest the name Mycoplasma phocidae; strain 105 is the type strain.

The isolation of mycoplasmas from the epizootic of pneumonia in seals in 1979 and 1980 has been described previously $(8,10,14)$. The necrotizing bronchitis and bronchiolitis and hemorrhagic alveolitis observed at necropsy were considered to be due to the influenza virus. Environmental factors and population density may have been contributing factors. The contribution of the mycoplasmas to the syndrome is not clear. Attempts to infect grey seals and harp seals with mycoplasma strain M4359 and/or the influenza 


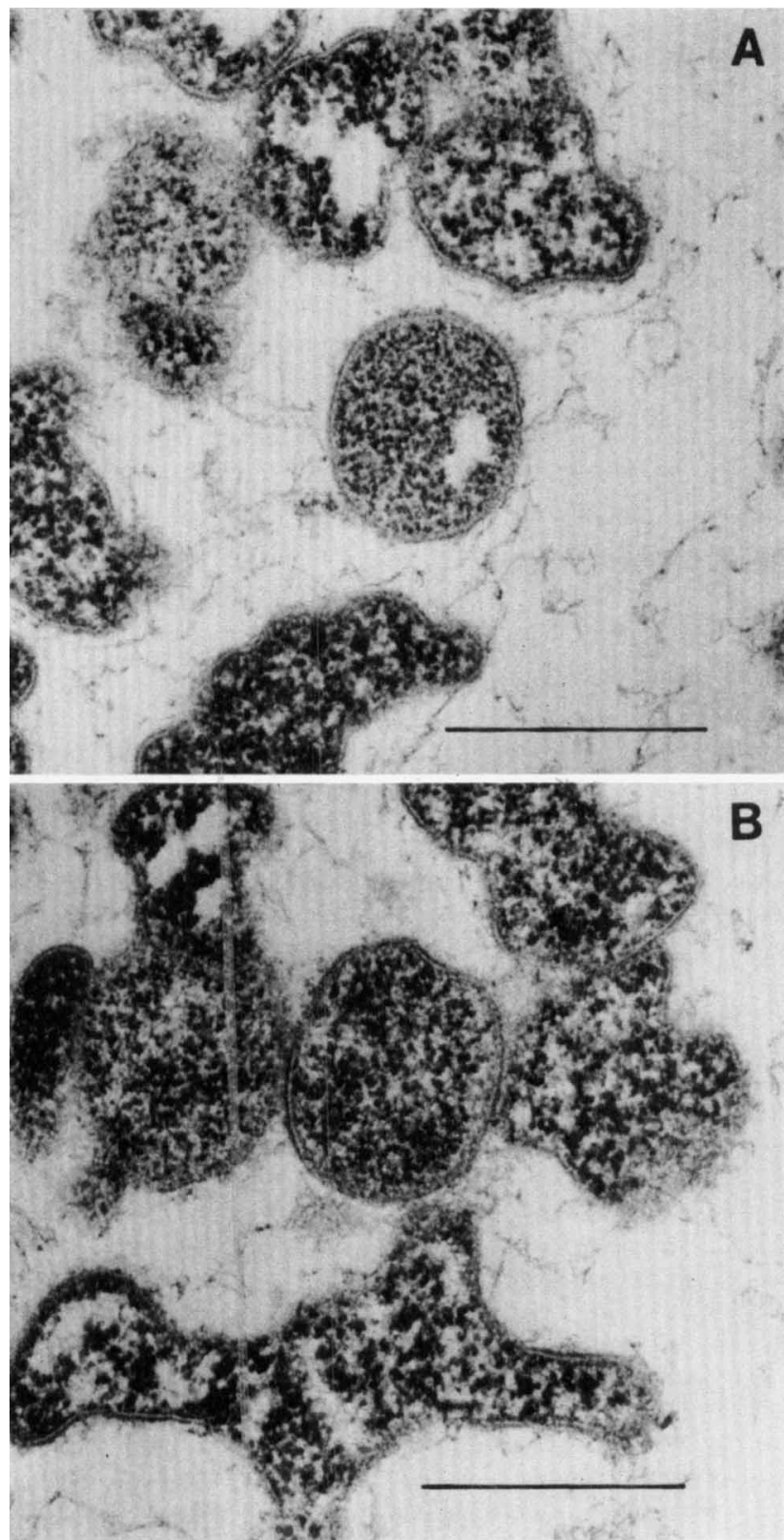

FIG. 1. Electron micrographs of ultrathin sections of seal mycoplasma strain $105^{\mathrm{T}}$, showing the trilaminar structure of the membrane and the complete absence of a cell wall. Bars $=0.5 \mu \mathrm{m}$.

virus have been described previously (9). No respiratory disease was observed, and no mycoplasma was recovered from any of the seals, although an unrelated mycoplasma was isolated from the mouths, eyes, lungs, and noses of all of the experimental seals.

Recently, Giebel et al. described $M$. phocarhinis and $M$. phocacerebrale, which were isolated from seals suffering from an epizootic of respiratory disease in the North Sea (11). These species are not related serologically to $M$. phocidae. In 1974 Smith et al. described the isolation of six mycoplasma strains from sea lions in an investigation of abortions, but these strains were never characterized (18).

Description of Mycoplasma phocidae sp. nov. Mycoplasma phocidae (pho'cid.ae. L. n. phoca, seal; phocidae, of a seal).
Thin sections reveal mainly coccoid forms with a clearly defined three-layer membrane and no cell wall. Colonies on agar have a typical fried egg appearance. The organism grows at $37^{\circ} \mathrm{C}$ microaerophilically or anaerobically. Cells pass through filters having pore diameters of $450 \mathrm{~nm}$ but are retained by filters having pore diameters of $220 \mathrm{~nm}$. The organism is resistant to penicillin and thallium acetate, and there is no reversion to bacterial forms in medium that lacks these substances.

Cultures are inhibited by digitonin and require serum for growth. Arginine is hydrolyzed, but glucose and urea are not. Film and spots are produced on horse serum agar. Phosphatase is produced. Tetrazolium is not reduced. Serum and casein are not digested. Alpha-hemolysis occurs on bovine blood agar. The organism hemagglutinates but does not hemadsorb on sheep, guinea pig, chicken, or seal erythrocytes.

The $\mathrm{G}+\mathrm{C}$ content of the DNA is $27.8 \mathrm{~mol} \%$.

The species is serologically distinct from other $\mathrm{Myco}$ plasma species.

The habitat is the respiratory tracts of harbor seals. The organism appeared to be avirulent following experimental inoculation of grey or harp seals (10), but it may contribute to respiratory disease of harbor seals in association with other infections or environmental factors.

The type strain is strain 105 (= ATCC 33657).

\section{ACKNOWLEDGMENTS}

We thank the following individuals: J. Geraci, University of Guelph, Guelph, Ontario, Canada, and A. S. Baker, Infectious Diseases Unit, Massachusetts General Hospital, Boston, for providing specimens from the New England Aquarium; Richard Del Giudice, Program Resources, Inc., Frederick, Md., and J. G. Tully and D. L. Rose, National Institute of Allergy and Infectious Diseases, Frederick, Md., for performing serological comparisons of the isolates; H. Kirchhoff for arranging for J. Flossdorf, Gesellschaft fur Biotechnologische Forschung, Braunschweig, Germany, to do DNA studies; Lois Parker and Jacquie Caccavella, Veterinary Laboratory Services, Guelph, and Maureen McVann Jerz, Department of Bacteriology, Massachusetts General Hospital, Boston, for technical assistance; and R. R. Bruns, Department of Developmental Biology, Massachusetts General Hospital, Boston, for the electron micrographs.

\section{REFERENCES}

1. Aluotto, B. B., R. G. Wittler, C. O. Williams, and J. E. Faber. 1970. Standardized bacteriologic techniques for the characterization of Mycoplasma species. Int. J. Syst. Bacteriol. 20:35-38.

2. Barker, I. K., J. R. Geraci, D. St. Aubin, L. Ruhnke, A. N. Gagnon, G. Lang, and A. S. Baker. 1980. Pathology of epizootic pneumonia in harbour seals (Phoca vitulina) associated with influenza A virus and Mycoplasma infection. Abstr. p. 26. Wildl. Dis. Assoc. Annu. Meet., Baton Rouge, La.

3. Clyde, W. A. 1964. Mycoplasma species identification based on growth inhibition by specific antisera. J. Immunol. 92:958-965.

4. Deines, L., and S. Bullivant. 1968. Morphology and reproductive processes of the L-forms of bacteria. II. Comparative study of L-forms and Mycoplasma with the electron microscope. J. Bacteriol. 95:672-687.

5. Del Giudice, R. A., F. Robillard, and T. R. Carski. 1967. Immunofluorescence identification of mycoplasma on agar by use of incident illumination. J. Bacteriol. 93:1205-1209.

6. Flossdorf, J. 1983. A rapid method for the determination of base composition of bacterial DNA. J. Microbiol. Methods 1:305311.

7. Freundt, E. A., B. E. Andrews, H. Erno, M. Kunze, and F. T. Black. 1973. The sensitivity of Mycoplasmatales to sodiumpoly-anetholsulfonate and digitonin. Zentralbl. Bakteriol. Parasitenkd. Infektionskr. Hyg. Abt. 1 Orig. Reihe A 225:104-112. 
8. Geraci, J. R., I. K. Barker, D. J. St. Aubin, and R. G. Webster. 1981. Epizootic pneumonia of harbour seals (Phoca vitulina), $\mathrm{p}$ 186-187. Wildl. Dis. Proc. 4th Int. Conf. Wildl. Dis. Assoc.

9. Geraci, J. R., D. J. St. Aubin, I. K. Barker, V. S. Hinshaw, R. G. Webster, and H. L. Ruhnke. 1984. Susceptibility of grey (Halichoerus grypus) and harp (Phoca groenlandica) seals to the influenza virus and Mycoplasma of epizootic pneumonia of harbor seals (Phoca vitulina). Can. J. Fish. Aquat. Sci. 41:151156.

10. Geraci, J. R., D. J. St. Aubin, I. K. Barker, R. G. Webster, V. S. Hinshaw, W. J. Bean, H. L. Ruhnke, J. H. Prescott, G. Early, A. S. Baker, S. Madoff, and R. T. Schooley. 1982. Mass mortality of harbor seals: pneumonia associated with influenza A virus. Science 215:1129-1131.

11. Giebel, J., J. Meier, A. Binder, J. Flossdorf, J. B. Poveda, R. Schmidt, and H. Kirchhoff. 1991. Mycoplasma phocarhinis sp. nov. and Mycoplasma phocacerebrale sp. nov. two new species from harbor seals (Phoca vitulina L.). Int. J. Syst. Bacteriol. 41:39-44.

12. Hayflick, L. 1965. Tissue cultures and mycoplasmas. Tex. Rep. Biol. Med. 23:285-303.
13. International Committee on Systematic Bacteriology Subcommittee on the Taxonomy of Mollicutes. 1979. Proposal of minimal standards for the description of new species of the class Mollicutes. Int. J. Syst. Bacteriol. 29:172-180.

14. Madoff, S., R. T. Schooley, H. L. Ruhnke, R. A. Del Giudice, I. K. Barker, J. Geraci, and A. S. Baker. 1982. Mycoplasmal pneumonia in phocid (harbor) seals. Rev. Infect. Dis. 4:S241.

15. Rosendal, S., and F. T. Black. 1972. Direct and indirect immunofluorescence of unfixed and fixed mycoplasma colonies. Acta Pathol. Microbiol. Scand. Sect. B 80:615-622.

16. Ruhnke, H. L., P. A. Doig, A. L. MacKay, A. Gagnon, and M. Kierstead. 1978. Isolation of ureaplasma from bovine granular vulvitis. Can. J. Comp. Med. 42:151-155.

17. Ruhnke, H. L., N. C. Palmer, P. A. Doig, and R. B. Miller. 1984. Bovine abortion and neonatal death associated with Ureaplasma diversum. Theriogenology 21:295-301.

18. Smith, A. W., C. M. Prato, W. G. Gilmartin, R. J. Brown, and M. C. Keyes. 1974 . A preliminary report on potentially pathogenic microbiological agents recently isolated from pinnipeds. J. Wildl. Dis. 10:54-59. 